\title{
Legislation of Pesticides in Citriculture, Community of Cubiteua, Capitão Poço/PA
}

\author{
M. T. R. Abade $^{1}$, M. E. L. Rocha ${ }^{1}$, J. A. M. Siqueira ${ }^{2}$, R. C. L. Siqueira ${ }^{3,4}$, F. L. B de Souza ${ }^{1}$, L. S. Cunha ${ }^{1}$, \\ L. L. O. Ribeiro ${ }^{1}$, M. S. S. Ribeiro ${ }^{1}$, M. T. Ávila ${ }^{5} \&$ K. C. Millomes Junior ${ }^{6}$ \\ ${ }^{1}$ Western Paraná state University, Marechal Cândido Rondon, Brazil \\ ${ }^{2}$ Federal Rural University of Amazonia, Capitão Poço, Brazil \\ ${ }^{3}$ Federal University of Pará, Belém, Brazil \\ ${ }^{4}$ SEDUC Professor, Capitão Poço, Brazil \\ ${ }^{5}$ Agronomist Engineer, Belém, Brazil \\ ${ }^{6}$ Agronomist Engineer, Capanema, Brazil \\ Correspondence: M. T. R. Abade, Agricultural Science Center, Western Paraná State University, 1777-Caixa \\ Postal 91, Marechal Cândido Rondon, Brazil. Tel: 55-045-3284-7916; 55-045-3284-7918; 55-045-98805-6803. \\ E-mail: mayra_agro2011@hotmail.com
}

Received: September 17, 2018

doi:10.5539/jas.v11n17p287
Accepted: August 12, $2019 \quad$ Online Published: October 15, 2019

URL: https://doi.org/10.5539/jas.v11n17p287

\begin{abstract}
The Brazilian citriculture presents hegemony in the production and export of orange juice. The state of São Paulo is the largest national producer, accounting for $74 \%$ of the national production of this fruit. The State of Pará is responsible for $1.02 \%$ of the production of Orange in Brazil, of that amount the municipality of Captain Poço is responsible for $57 \%$ of the total produced. The objective of this research was to analyze the profile of different producers in compliance with the pesticide legislation. For the development of the work, a survey was carried out based on the Law of Agrochemicals-Law No. 7,802 of July 11, 1989 and the Law of Packaging-Law No. 9,974 of June 6, 2000, in the community of Cubiteua belonging to the municipality of Captain Poço/PA. The producers interviewed were chosen based on planted area and these were typified according to the amount of citrus planted. The percentage of respondents who know Federal Law 7,802/89, rectified by Law 9,974/00 and regulated by Decree No. 4,074/02, is equal to $8 \%$. Both laws are not known to most producers, especially those with the smallest planted area, and as a consequence, they are not being met, leading to environmental, social, economic and human health problems.
\end{abstract}

Keywords: citrus, herbicide, producer

\section{Introduction}

The Brazilian citriculture presents global hegemony in the production and export of orange juice (FAO, 2015). According to Neves et al. (2010), in 2009, exports of the citrus complex amounted to 2.9 million tons, with Brazil accounting for $50 \%$ of the world production of orange juice, and $98 \%$ of its production is exported. Recently, orange juice, one of the main export products has caught the attention of the world press on pesticide residues, considering that Brazil is the world's largest consumer of this product and the largest exporter of orange juice in the world, it seems obvious the relationship (Dorfman, 2013).

In relation to the area planted in the 2016 harvest (14,562 ha) and in the 2017 harvest (19,315 ha), there was a variation of $32.6 \%$. While in the area harvested, in the 2016 harvest was 13,480 ha, in 2017 it was 13,650 ha, with a variation of $1.3 \%$ (IBGE, 2017). This state accounts for $1.02 \%$ (258,758 tons) of Orange production in Brazil, of which the municipality of Capitão Poço produces 57\% (146,370 tons) of the total produced by the State (IBGE, 2015a).

Even though the state of Pará is not among the largesr citrus growers in the country, the Capitão Poço municipality has gained prominence in the national citrus industry in recent years. CapitãoCapitão Poço is the largest producer of Laranja in the north of Brazil, with orange being the largest economic source, generating 
around 50 million reais and about 30 thousand direct and indirect jobs temporarily, or almost $60 \%$ of the population of the municipality (52 thousand inhabitants) (IBGE, 2015b).

Studies on the impacts of conventional agriculture on the health of the rural worker by the use of agrochemicals is an area of investigation of extreme importance and still incipient in Brazil. The studies carried out in this field indicate the underreporting by health agencies when it comes to intoxications due to inappropriate and excessive use of pesticides, with repercussions on the health of the worker and the consumer (Leite \& Torres, 2008).

The Law No. 7,802, Law of Agrochemicals of July 11, 1989, provides for research, experimentation, production, packaging and labeling, transportation, storage, commercialization, commercial advertisement, use, import, export, final destination of waste and packaging, registration, classification, control, inspection and inspection of pesticides, components and the like (MAPA, 1989). The inspection of the correct destination of empty containers of pesticides is based on Law 9,974 of June 6, 2000, which amends Law No. 7,802 of July 11, 1989.

In view of the above, this research had the objective of analyzing the profile of different producers in complying with the pesticide legislation.

\section{Method}

The town of Cubiteua is located $8 \mathrm{~km}$ from the township of Captain Poço, which is located at latitude $01^{\circ} 44^{\prime} 47^{\prime \prime}$ $\mathrm{S}$, Longitude $47^{\circ} 03^{\prime} 34^{\prime \prime} \mathrm{W}$, altitude $73 \mathrm{~m}$ and total area equal to $2,727 \mathrm{~km}^{2}$. According to Köppen classification, the climate is of type Am, annual rainfall around $2,500 \mathrm{~mm}$, with a short dry season between September and November, average temperature of $26^{\circ} \mathrm{C}$ and relative humidity between $75 \%$ and $89 \%$ in the months with lower and higher rainfall, respectively (Schwart, 2007).

The period of analysis of this study was from June 2015 to January 2016. The questionnaires were applied to the citrus producers in the community. The producers interviewed were chosen based on the area planted and these were typified according to the amount of citrus planted (Table 1). In this classification it was sought to homogenize the interviewees, framing them in profiles that resembled and to reduce possible repeated information, evaluating the individual and group behavior within the diverse situations and questions that were submitted.

Table 1. Typification of the producers according to the quantity of plants in each area in the community of Cubiteua, municipality of Capitão Poço, PA

\begin{tabular}{lll}
\hline Typification of producers & Number of plants & Quantity of producers \\
\hline Type 1 & Below 5000 & 5 \\
Type 2 & $5000-10000$ & 5 \\
Type 3 & $10000-20000$ & 5 \\
Type 4 & Above 20000 & 5 \\
\hline
\end{tabular}

For the development of the work, questionnaires were applied (based on the Law of Agrochemicals-Law No. 7,802, of July 11, 1989 and in the Packaging Law-Law No. 9.974, of June 6, 2000) in the community of Cubiteua belonging to the municipality of Captain Poço/PA.In order to ensure the quality of the information, some fundamental procedures were adopted during the data collection phase. Firstly, the agricultural director or manager of each property was identified, sufficiently familiar with the concepts of pesticides and general information regarding the procedures performed in the area and that supposedly had the technical condition to pass on the information required, the questions were highly specialized. Once this professional was identified, he was asked to visit his property, in which the questionnaires were applied.

The citrus production units were surveyed using data provided by the local Office of the Technical Assistance and Rural Extension-Emater/PA, which suggested the delimitation of strategic and influential areas in the citrus production of the municipality, since according to the recommendation of the local office's agronomic engineer, the indicated community presents significant production and great diversity, and the producers that concentrate larger areas and production, so that the typification is as close as possible to the reality of the region.

Data analysis was performed using simple descriptive statistics using Excel software. From this, graphs and tables were elaborated to represent the qualitative data obtained. 


\section{Results and Discussion}

In the study, $90 \%$ of the Cubiteua community interviewees confirmed that citriculture was their main agricultural activity. When instigated on the beginning of citrus plantations in the region most of the producers interviewed said that it occurred shortly after the decimation of passion fruit plantations by the bacterial wilt disease caused by the bacterium Raistonia solanacearum brought from the state of São Paulo by a farmer of the time.

Citrus fruits generate jobs in the community, generating both direct and indirect income, especially in the harvest season. According to producers, almost all of the labor employed in cultivation is provided by the community itself. Manpower is essential for planting success and its source varies in relation to the amount of citrus tree planted (Table 2).

Table 2. Profile of producers and their various forms of production within the agricultural scenario of Cubiteua, municipality of Capitão Poço, PA

\begin{tabular}{llll}
\hline Typification of producers & Labor & Area cleaning & $\begin{array}{l}\text { Technical assistance (\%) } \\
\text { Yes/No }\end{array}$ \\
\hline Type 1 & Family & Brush Cutter/Chemistry & $33.33 / 66.67$ \\
Type 2 & Family/Contractor & Brush Cutter/Chemistry & $33.33 / 66.67$ \\
Type 3 & Family/Contractor & Brush Cutter/Chemistry & $66.67 / 33.33$ \\
Tipo 4 & Contractor & Brush Cutter/Chemistry/Tractor & $66.67 / 33.33$ \\
\hline
\end{tabular}

As can be seen in Table 2, in type 1, the workforce is exclusively family-run, according to the producers, production does not compensate for the contraction of external service, since when it comes to types 2 and 3 , labor is also contracted, and contraction occurs mainly at the time of harvest. Type 4 is a separate case, in which all the labor used throughout the cropping system is contracted, being justified by high productivity and planted area.

The cleaning of the area in types 1, 2 and 3 (Table 2) is done with the help of brushcutter and the application of chemical. The brushcutter is a tool of recent use in the region's agriculture, however, it has been growing considerably in recent years, according to growers it is due to its low cost of acquisition, easy handling and efficiency in the control of spontaneous plants.

Producers type 4 , in addition to brushcutters and chemical products, use a tractor for cleaning and application of pesticides in the area. According to the producers, the greater number of trees planted justifies the increase of this implement in the system, since these producers concentrate a greater amount of trees planted, and as a consequence the work increases, the profits also, propitiating the acquisition of more sophisticated machines.

Technical assistance on rural properties, mainly in northern Brazil, is often flawed and precarious, where the extensionist/producer relationship is very small, especially for farmers in smaller areas and lower incomes. Table 2 shows that in types 1 and 2, only $33.33 \%$ of the respondents receive technical assistance, according to the same, this is done by technicians from the local office at Emater/PA, once or twice a year, while that in types 3 and 4, $66.67 \%$ of respondents receive assistance, however, in these types, assistance is mostly contracted.

In a study by Alves et al. (2013) in the orange crop in the municipality of Cubiteua, $86 \%$ of the producers stated that they did not have this type of service, only $14 \%$ answered positively.

It is worth noting that lack of assistance makes it impossible to disseminate specific information on the application of pesticides, which contributes to formulation and application errors, thereby increasing the potential risks of contamination of the environment and farmers, which are almost all involved in the agricultural process (Ribas \& Matsumura, 2009).

In the study of Table 3, it was observed that $100 \%$ of type 1, 3 and 4 producers only buy the sealed product, because according to them the seal serves as a guarantee that they are buying the desired product without manipulation by the seller, both in volume and in chemical, physical and biological characteristics. For type 2, $66.67 \%$ of respondents buy product even in the absence of sealing, in this type an interesting data is that $33.33 \%$ of respondents are indifferent to the presence or absence of sealing. 
Table 3. Presence of seal, overdue product and place of purchase of agrótoxico by producers of the community of Cubiteua, municipality of Capitão Poço, PA

\begin{tabular}{llll}
\hline \multirow{2}{*}{ Typification of producers } & $\begin{array}{l}\text { Buy sealed product } \\
\text { Yes/No/Indifferent }\end{array}$ & $\begin{array}{l}\text { Purchase overdue product } \\
\text { Yes/No/Indifferent }\end{array}$ & Product purchase location \\
\hline Type 1 & $100 / 0 / 0$ & $0 / 66.67 / 33.33$ & Capitão Poço \\
Type 2 & $66.67 / 0 / 33.33$ & $33.33 / 66.67 / 0$ & Capitão Poço/Paragominas \\
Type 3 & $100 / 0 / 0$ & $0 / 100 / 0$ & Capitão Poço/Paragominas/Maranhão \\
Type 4 & $100 / 0 / 0$ & $0 / 100 / 0$ & Capitão Poço/Paragominas/Maranhão \\
\hline
\end{tabular}

The expiration date of the product guarantees to the purchaser that the product purchased still maintains the characteristics guaranteed in the package insert. In this research (Table 3), the most striking fact is the type 1, where $33.33 \%$ of respondents are indifferent to the purchase of the overdue product, that is, $33.33 \%$ of them do not look at the product's expiration date at the time of purchase, being subject to purchase of products without guarantee of production gain, and may be an expense without economic return.

Another very pertinent data is referring to type 2 , where $33.33 \%$ of respondents already compare or buy products with expired expiration date, because when buying these products receive discounts on the purchase, this encourages them to buy. In types 3 and 4, 100\% of the respondents never bought or did not buy overdue products, according to the producers do not buy because, due to the large number of trees planted, the application of overdue product could cause irreversible crop damage and consequently disastrous economic losses.

The place of purchase of pesticides is different among the types of producers, type 1 buy exclusively in the market of Captain Well, because they require small volumes not compensating the displacement to other cities. In type 2, the purchase is made in Capitão Poço and Paragominas, already in types 3 and 4 the purchase is made in Capitão Poço, Paragominas and Maranhão, being made in Captain Poço only in specific situations, for example when the product ends and not is economically viable due to the small quantity going to Paragominas or in Maranhão buying it (Table 3). Still according to the interviewees, the purchase in Capitão Poço is limited by the costly price when compared to the other points of sale.

The participation in association is shown in Table 4, where it is observed that $100 \%$ of the type 2 producers participate, these have smaller plantations and the association facilitates the cheaper purchase of the supplements. As for the participation in a lecture still in Table 4, the result was the same, that is, in all types $66.67 \%$ of respondents participated and $33.37 \%$ did not participate.

Table 4. Insertion and participation of the producers of Cubiteua, in associations and lectures

\begin{tabular}{lll}
\hline Typification of producers & $\begin{array}{l}\text { Participate in association (\%) } \\
\text { Yes/No }\end{array}$ & $\begin{array}{l}\text { Participate in lectures (\%) } \\
\text { Yes/No }\end{array}$ \\
\hline Type 1 & $33.33 / 66.67$ & $66.67 / 33.37$ \\
Type 2 & $100 / 0$ & $66.67 / 33.37$ \\
Type 3 & $33.33 / 66.67$ & $66.67 / 33.37$ \\
Type 4 & $33.33 / 66.67$ & $66.67 / 33.37$ \\
\hline
\end{tabular}

Although most interviewees claim to attend lectures, it was found that they are not focused on the use and destination of agrochemical packaging, which brings us to the idea that rural producers are not being correctly instructed in the use, handling, storage and disposal of empty agrochemical packaging, thus leading them to commit inflation to the law. 


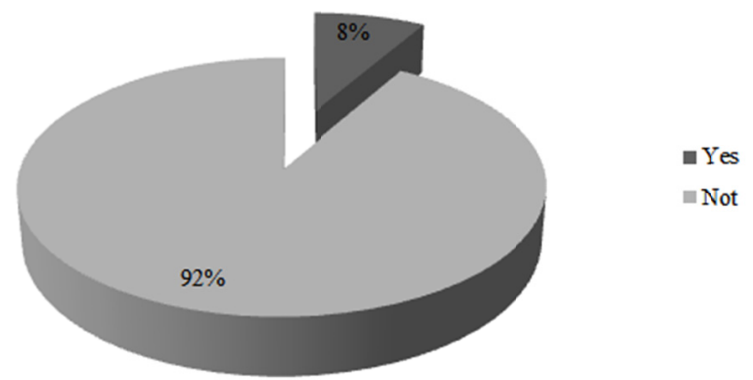

Figure 1. Knowledge of pesticide and packaging legislation in the region of Cubiteua, in the municipality of Capitão Poço

In the evaluation of Table 5, it was observed that $100 \%$ of the type 1 producers read the label, in contrast the type 2 producers, $100 \%$ do not read the label/bula, in this type the lack of reading is not reported only due to the lack of interest of the producers, but also because some of them did not know how to read.

Table 5. Profile of the producers regarding the package leaflet, the grace period and indication range for the use of chemical products in the region of Cubiteua, in the municipality of Capitão Poço, PA

\begin{tabular}{llll}
\hline Typification of producers & $\begin{array}{l}\text { Read label/Bull (\%) } \\
\text { Yes/No }\end{array}$ & $\begin{array}{l}\text { Obey the grace period (\%) } \\
\text { Yes/No }\end{array}$ & $\begin{array}{l}\text { Observe the product indication range (\%) } \\
\text { Yes/No/Indifferent }\end{array}$ \\
\hline Type 1 & $100 / 0$ & $0 / 100$ & $100 / 0 / 0$ \\
Type 2 & $0 / 100$ & $0 / 100$ & $33.33 / 66.67 / 0$ \\
Type 3 & $66.67 / 33.33$ & $33.33 / 66.67$ & $33.33 / 66.67 / 0$ \\
Type 4 & $66.67 / 33.33$ & $57.14 / 42.86$ & $66.67 / 33.33 / 0$ \\
\hline
\end{tabular}

In a study in the same community Alves et al. (2013) observed that it was noticeable that the producers had a low degree of education, since only $17.86 \%$ of the interviewees had completed high school, in which the majority only read and write. This fact may have functioned as limiting in the interpretation and performance of the prescribed label procedures.Still according to Table 5, in types 3 and 4, 66.67\% of the interviewees read the label/package insert, but in some cases the reading is done only when they buy the product, not reproducing the recommendations at the time of application. The observation of the grace period is essential so that the food harvested does not have residue of the pesticide at levels above the maximum limit allowed by the Ministry of Health. The marketing of agricultural products containing pesticide residue at levels above the maximum limit set by the Ministry is illegal and is subject to penalties provided by law. If the grace period is not obeyed properly, the risks to human health, animals and the environment are immeasurable.

According to Table 5, 100\% of respondents of types 1 and 2 do not obey the grace period of the product that is prescribed in the package leaflet, according to them, as the applications are made in the bush and not directly in the fruit, there is no contamination. In types 3 and 4, only $33.33 \%$ obey.

Type 4 presents a peculiar characteristic when compared to the others, since only in this type, there were interviewees who were indifferent to the grace periods, and these represent $33.33 \%$ of the total interviewees. This last issue requires attention, because in this type large volumes of production are concentrated, that is, they are responsible for most of the citrus that go to the consumer's table.

According to Table 5, in type 1 only, $100 \%$ of the producers observe the indication range of the product, this can be explained by the fact that this information is included in the product insert, and in this type $100 \%$ of the interviewees read the it. In types 2, 3 and 4, 33.33\%, 33.36\%, 66.67\%, respectively, observed the color of the strip before the purchase. According to type 4 producers, the color of the strip does not interfere with the time of purchase, they observe only to take the necessary care at the time of handling the product.

Prior to the application of the product these need to be stored, and according to federal legislation this site should be fresh, dry and ventilated, however what is observed in Chart 2 is that the products are stored in unsuitable environments such as room (10\%) located inside the house; sheds (60\%) and shack (30\%). During the interview it was detected that the sheds and shacks are located near the residences, being able to be source of contamination for humans and animals. 


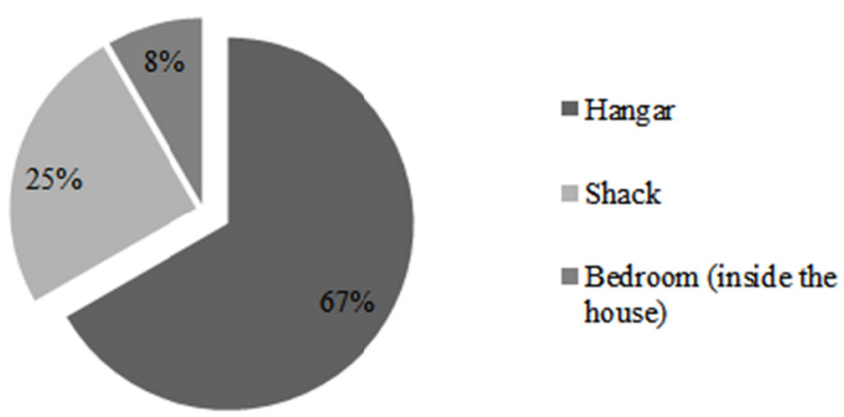

Figure 2. Storage locations of packagings containing agrochemicals

According to Table 6, in types 1, 2 and 3,100\% of farmers do not give correct destination to empty agrochemical containers. The only type that makes the return is the 4 , where $66.67 \%$ claim to return the packaging to the commercial houses and central receiving after use. The destinations given to the waste are the most varied, and some are reused (transporting fuel and transporting water for subsequent spraying).

Table 6. Use and destination of the packaging by the producers of Cubiteua, in the municipality of Capitão Poço, PA

\begin{tabular}{llll}
\hline \multirow{2}{*}{ Typification of producers } & $\begin{array}{l}\text { Correct destination for packaging }(\%) \\
\text { Yes/No }\end{array}$ & $\begin{array}{l}\text { Return of packaging (\%) } \\
\text { Yes/No }\end{array}$ & $\begin{array}{l}\text { Reuses packaging (\%) } \\
\text { Yes/No }\end{array}$ \\
\hline Type 1 & $0 / 100$ & $0 / 100$ & $33.33 / 66.67$ \\
Type 2 & $0 / 100$ & $0 / 100$ & $66.67 / 33.33$ \\
Type 3 & $0 / 100$ & $0 / 100$ & $100 / 0$ \\
Type 4 & $66.67 / 33.33$ & $66.67 / 33.33$ & $33.33 / 66.67$ \\
\hline
\end{tabular}

Although the return of packaging is provided by federal law, it was observed in the research that this procedure is done by the minority of the interviewees. According to Table $6,100 \%$ of type 1,2 and 3 farmers do not return packs, while in Type 4, 66.67\% of farmers return. Based on these data, it is observed that the type 4 producers, owners of the largest quantities of citrus trees planted, are the only ones to return the packages, a fact justified by them as a reflection of the ease in information and mainly the large volume of packages purchased. Producers type 1, 2 and 3 do not have access to the same information and because they buy in smaller volume and in local commerce, they are not charged for the return.

In Table $6,100 \%$ of the type 3 producers reuse the empty containers for other purposes. In type 1 and $4,33.33 \%$ reuse the packaging and in type 2, 66.67\% reuse. The packaging used for other purposes is mainly the one of greater volume, above 20 liters, these have as main purpose the transport of water for later spraying. The interviewees did not report the use of packaging for the storage of water for human or animal consumption.

In the same community it was identified that $60.7 \%$ wash and use for other purposes, $17.9 \%$ wash and store in deposits that in some cases are used again and in others they are disposed of in the domestic refuse, only $3.5 \%$ specialized collection points (Alves et al., 2013).

According to Lima et al. (2008), inadequate fate of packaging contributes to contamination of soils and waters, as well as chemical residues found in foods grown with these compounds.

According to article 6, paragraph 5 of Law No. 7,802, of July 11, 1989, says that: the companies that produce and commercialize agrochemicals, their components and the like, are responsible for the disposal of the empty packaging of products manufactured and marketed by them, after the return by the users, and for the products seized by the inspection action and those unfit for use or in disuse, with a view to their reuse, recycling or destruction, obeying the rules and instructions of the relevant registrants and sanitary-environmental bodies (Added by Law 9,974/2000).

According to Graph 3, the destination of the packaging as described in the law, is done by only $25 \%$ of the interviewees, the rest of the different purposes the packaging, and $19 \%$ burn, for evaluating as the correct way to proceed or because they do not have other alternatives, because when the containers begin to tumultuous they 
prefer to give this purpose, $37 \%$ reuse to transport water for later sprays, $13 \%$ play in the field after application and $6 \%$ use to transport fuels.

According to the interviewees, they are not told by sellers about the need to return empty containers to the place of purchase, and the lack of information cited by them as the main limitation for non-return of packaging, besides factors such as logistics and accessibility to proceed with the return. Accordingly, the actions for the collection of empty containers, as determined by Decree 4,074 of January 4, 2002, in this community are not carried out satisfactorily.
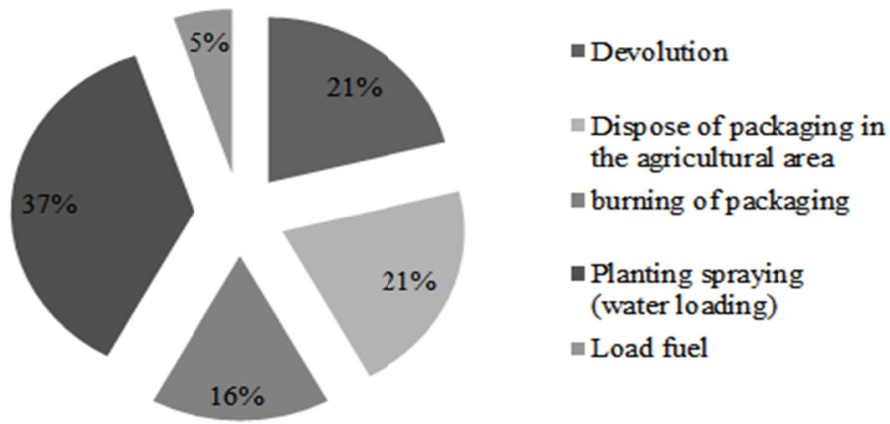

Figure 3. Final destination of the pesticide containers after use of the product

According to the data in Table 7, 33.33\% of respondents in both type 1 and 3, say they have already suffered some type of accident with the use of pesticides, both in the preparation of the syrup and in the field application of the product. On the other hand, 100\% of types 2 and 4 interviewees stated that they had never had accidents during the application. However, although there were no reports of accidents in both types, this does not mean that this was not the case, since in some cases contamination is only evident after long periods.

An important factor in case of accidents is the care to be taken if they happen, however, with the work it was observed that $100 \%$ of respondents of all types would not know what to do or who to turn to in this situation. This condition deserves carefulness, as these farmers deal daily with these products, are continually exposed to their damages and do not even know how to proceed in more extreme cases.

In a study carried out by Alves et al. (2013) in the same community, but only focused on orange cultivation, about $75 \%$ of respondents did not receive guidance on the proper use of pesticides, and only $25 \%$ received some kind of guidance.

According to the analysis in Table 7, it is possible to observe that $100 \%$ of the interviewees in types 1,2 and 3 do not use Agronomic Recipes, according to the same they are not charged at the time of purchase of the product, therefore, they do not see the necessity of their use. In type 4,66.67\% use, a result that can be explained by the fact that type producers of this type, have greater access to information, higher income, higher plantations and have at least one technician in the property.

The Personal Protective Equipment (PPE) ensures the safety of the worker in preparing the syringe and applying the product. In the survey when questioned about the use of PPE, 100\% of respondents type 1, 2 and 3 do not use the same, being justified by: discomfort of the applicator, rejection of the equipment by the same, do not have PPE in the property. In type 4, fleeing the reality of the other types $33.33 \%$ of respondents use or supply equipment to employees, very low value, when compared to the need of the use of the equipment and the health risk of the applicator/producer.

Gregolis et al. (2012) in their research found similar results when analyzing the risks of exposure of pesticides to family farming workers in the municipality of Rio Branco, state of Acre, in which most of the interviewees stated that they did not need PPE and therefore did not have the equipment on your property. The risks of exposure to pesticides can be reduced if care is taken such as the use of PPE.

\section{Conclusion}

Both laws are not known to most producers, especially those with the smallest planted area, and as a consequence, they are not being met, leading to environmental, social, economic and human health problems. 
There was also a lack of information on the part of the producers, being this factor that most interferes in the length of the legislation. The technical assistance received is insufficient and fails, and does not effectively address the need for conscious use and correct disposal of the packaging after use.

\section{References}

Alves, J. D. N., Oliveira, S. S., Mota, A. M., Almeida, R. H. C., \& Okumura, R. S. (2013). Percepção de riscos no uso de agrotóxicos na cultura da laranja pela comunidade do Cubiteua, município de Capitão Poço-PA. Enciclopédia Biosfera, 9(17), 3597. Retrieved June 20, 2015, from http://www.conhecer.org.br/ enciclop/2013b/MULTIDISCIPLINAR/percepcao.pdf

FAO (Food and Agriculture Organization of the United Nations). (2015). Production. FAOSTAT. Retrieved March 20, 2017, from http://faostat.fao.org

Gregolis, T. B. L., Pinto, W. J., \& Peres, F. (2012). Percepção de riscos do uso de agrotóxicos por trabalhadores da agricultura familiar do município de Rio Branco, AC. Revista Brasileira de Saúde Ocupacional, 37(125), 99-113. https://doi.org/10.1590/S0303-76572012000100013

IBGE (Instituto Brasileiro de Geografia e Estatística). (2015a). Pesquisa agrícola municipal. Rio de Janeiro, Brazil. Retrievd March 8, 2017, from http://www.sidra.ibge.gov.br

IBGE (Instituto Brasileiro de Geografia e Estatística). (2015b). Rio de Janeiro, Brazil. Retrievd March 8, 2017, from http://www.sidra.ibge.gov.br

IBGE (Instituto Brasileiro de Geografia e Estatística). (2017). Banco de dados agregados-SIDRA-Levantamento Sistemático da Produção Agrícola. Rio de Janeiro, Brazil. Retrievd March 8, 2017, from http://www.sidra.ibge.gov.br

Leite, K. C., \& Torres, M. B. R. O. (2008). Uso de Agrotóxicos pelos Trabalhadores Rurais do Assentamento Catingueiro Baraúna-RN. Revista Verde, 3(4), 06-28. Retrieved December 27, 2015, from http://www.gvaa.com.br/revista/index.php/RVADS/article/view/121/121

Lima, P. J. P. (2008). Possíveis doenças físicas e mentais relacionadas ao manuseio de agrotóxicos em atividades rurais, na região de Atibaia, SP/Brasil (158f., Dissertação (Mestrado em Saúde Pública), Universidade de São Paulo, São Paulo).

MAPA (Ministério da Agricultura, Pecuária e Abastecimento). (1989). Sistema de Consulta à Legislação-SISLEGIS. Retrieved June 15, 2015, from http://sistemasweb.agricultura.gov.br/sislegis/ action/detalhaAto.do? method=consultarLegislacaoFederal

Ribas, P. P.; Matsumura, A. T. S. (2009). A química dos agrotóxicos: impactos sobre a saúde e meio ambiente. Revista Liberato, 10(14), 149-158. Retrieved December 27, 2015, from http://www.liberato.com.br/sites/ default/files/arquivos/Revista_SIER/v.\%2010,\%20n.\%2014\%20(2009)/3.\%20A\%20qu\%EDmica\%20dos\% 20agrot\%F3xicos.pdf

Schwart, G. (2007). Manejo sustentável de florestas secundárias: Espécies potenciais no Nordeste do Pará, Brasil. Amazônia: Ciência \& Desenvolvimento, 3(5), 125-147. Retrieved August 14, 2015, from http://www.alice. cnptia.embrapa.br/alice/handle/doc/578357

\section{Copyrights}

Copyright for this article is retained by the author(s), with first publication rights granted to the journal.

This is an open-access article distributed under the terms and conditions of the Creative Commons Attribution license (http://creativecommons.org/licenses/by/4.0/). 